\title{
Non-specific occupational health conditions among brass workers at Gadaladeniya, Sri Lanka
}

\author{
Pushpa L Jayawardana ${ }^{1}$
}

(Index words: Blood copper and zinc levels, metal fume fever)

\begin{abstract}
Objective To determine the effect of exposure to metal dusts, fumes and high temperature levels among brass workers in comparison to a control group.

\section{Study design Analytical cross-sectional study.}

Methodology One hundred and fifty four brass workers were matched for age with 154 controls selected from the local population. An interviewer-administered questionnaire was used to determine the presence of acute and chronic symptoms and metal fume fever. Haemoglobin and blood zinc and copper levels were measured using the cyanmethaemoglobin technique and atomic absorption spectrophotometry respectively. Thermal environmental measurements were carried out by determining wet bulb and globe temperature (WBGT) levels and air velocity.
\end{abstract}

Results Among the chronic symptoms anorexia $(\mathrm{OR}=$ 3.3), distaste $(\mathrm{OR}=8.3)$, and aches and pains $(\mathrm{OR}=4.0)$ were significantly higher in the study group. Among the acute symptoms at work, cough $(\mathrm{OR}=4.2$ ), dry nose ( $O R$ $=6.8)$, tearing $(\mathrm{OR}=6.3)$, and itchy eyes $(\mathrm{OR}=6.3)$ were significantly higher in the study group. Sweating was significantly higher in the control group. Metal fume fever was significantly higher among the study group with an OR of 7.6. Levels of both copper and zinc were significantly higher in the study group, although both median and mean values were lower than the normal reference ranges. The recommended WBGT level of $26.1^{\circ} \mathrm{C}$ for an air velocity of less than $1.53 \mathrm{~m} / \mathrm{s}$ for heavy work was exceeded only in two workshops.

Conclusions Prevalence of non-specific symptoms was higher among brass workers. It is necessary to take preventive measures.

\section{Introduction}

Brass is a metal alloy composed mainly of copper and zinc. In addition, it may contain metals such as tin, lead, iron, manganese, nickel and others. In the analysis of the scrap brass that is used as a raw material for the manufacture of brassware, the composition was found to be $6.9 \%$ copper, $26.9 \%$ zinc, $3.5 \%$ tin, $1.7 \%$ lead and a trace of iron.

The manufacture of brassware consists of several labour intensive processes described elsewhere [1]. The first is smelting of scrap metal which generates various metal fumes depending on the constituents of the metal alloy. Metal fumes may also be released during welding. Smelting requires high temperatures, exposing the workers to adverse effects of heat. Acute effects of exposure to metal fumes are irritation of eyes, nose and throat $[2,3]$.

Zinc is thought to give rise to numerous gastrointestinal (GI) symptoms such as gastroenteritis, and gastric and duodenal ulcers $[4,5]$. Workers of copper and zinc refineries were reported to have significantly high cause specific standardised mortality ratios for cancer of the digestive and respiratory tracts and cerebrovascular disease [6].

A condition known to develop as a result of exposure to copper and zinc fumes is metal fume fever (MFF) [6, $7,8]$. It usually occurs few hours after exposure, when the worker resumes duty after being away from work. It is preceded by non-specific symptoms such as dry throat, metallic taste, cough, tightness in the chest and vomiting, followed by chills and rigours with a rise in temperature, which resolves by crisis a few hours later. It is accompanied by profuse sweating and the prostration may last several hours. The patient may fall into deep sleep and wake up weak but not incapacitated. However, it does not lead to long term complications $[2,7,8]$.

Heat is a physical hazard encountered in foundries and gives rise to acute conditions such as cramps, heat exhaustion and heat stroke. Chronic heat illness may present as weakness, irritability, nausea, vertigo, impotence and gastric pain [9].

${ }^{1}$ Senior Lecturer, Department of Community and Family Medicine, Faculty of Medicine, Ragama, Sri Lanka. Correspondence: P J. (Competing interests: none declared). Received 12 May 2003 and revised version accepted 11 September 2004. 
The aim of this study was to determine the effect of exposure to zinc, copper and lead dusts and fumes, and high temperature levels on brass workers in comparison to a control group.

\section{Methods}

A sample size of 170 was computed (minimum sample size of $147+5 \%$ for exclusions and $10 \%$ for nonresponse) and the brass workers were selected using the simple random sampling technique. An equal number of people were selected as the controls from the local population who resided in the same Medical Officer of Health area using cluster sampling. They were either unemployed or engaged in jobs other than the brass industry. The control group was matched for the age of the brass workers [1].

A questionnaire which was interviewer administered consisted of socio-demographic data, history of hospitalisation during the past 2 years, chronic symptoms in relation to GI and musculo-skeletal (MS) systems, acute symptoms experienced while at work during the previous 2 weeks and symptoms related to MFF. Questions pertaining to the latter two components were administered only to those who were employed in the control group. MFF was defined as presence of two or more of the following symptoms subsequent to resuming work after being away for a day or more: headache, dry cough, tightness of the chest, distaste in the mouth, feverishness and fever with or without chills [8]. The haemoglobin level was determined by spectrophotometry using a cyanmethaemoglobin technique. Whole blood copper and zinc levels were determined by atomic absorption spectrophotometry (AAS).

Environmental measurements were carried out in 10 randomly selected workshops from a total of 53. The WBGT index [10] for indoor conditions was used as a measure of thermal environment where $\mathrm{WBGT}=0.7 \mathrm{t}$ $+0.3 \mathrm{t}_{\mathrm{g},}\left(\mathrm{t}_{\mathrm{nwb}}=\right.$ natural wet bulb temperature, $\mathrm{t}_{\mathrm{g}}=$ globe temperature). The natural wet bulb and globe temperature were measured using the Mason's wet and dry bulb thermometer and the globe thermometer, respectively. Both instruments were suspended $0.8-0.9 \mathrm{~m}$ above the furnace (corresponds approximately to the centre of the body of the worker). Globe temperature was measured after 30 minutes of suspension and the wet bulb temperature was read when the thermometer became stabilised under natural ventilation.

Air velocity (AV) near the furnace was determined using the Kata thermometer, and the nomogram provided. $\mathrm{AV}$ is dependent on the dry bulb temperature and the cooling time, both of which were measured using the Kata thermometer and the Kata factor engraved on the stem of the Kata thermometer.

All the measurements were commenced 1 hour after the furnaces were lit and were recorded every hour for 3 hours in the morning. A total of 30 measurements were made from the 10 workshops.
Statistical analysis consisted of paired t-test for quantitative data, and Mc Nemar's and Binomial test for matched, and chi-square test for unmatched qualitative data. Zinc and copper levels were expressed as both mean (to enable comparison with other studies) and median (because blood metal levels were not normally distributed). The results were expressed as odds ratio (OR) and 95\% confidence intervals $(95 \% \mathrm{CI})$. Ethical approval was obtained from the Faculty of Medicine, Peradeniya.

\section{Results}

Total number of pairs analysed were 154 . The mean age of the two groups was 29.9 years. The pack years smoked was 8.6 and 11.4 by the smokers in the study group $(\mathrm{n}=71 ; 46.1 \%)$ and the control group $(\mathrm{n}=76$; $49.4 \%$ ) respectively, the differences of which were not significant. Only 104 members in the control group were employed and modal period of service ranged between 5 and 9 calendar years for both the groups.

Among the chronic symptoms studied, the proportion suffering from anorexia and distaste were significantly higher in the study group with OR of $3.3(95 \%$ $\mathrm{CI}=1.6-7.0)$ and $8.3(95 \% \mathrm{CI}=2.9-23.3)$ respectively. Although the proportion suffering from burning sensation was higher in the study group, the difference was not significant. Nausea and abdominal pain although more common in the control group, no statistically significant differences were observed. Only one person complained of constipation and he was a brass worker (Table 1). The proportion with aches and pains was significantly higher in the study group (Table 1) with an OR of $4(95 \%$ $\mathrm{CI}=2.3-7.0)$.

Among the acute symptoms studied, cough, dryness of nose, excessive tearing and itchy eyes were significantly more in the study group (Table 2), the OR being 4.2 $(95 \% \mathrm{CI}=1.5-13.0), 6.8(95 \% \mathrm{CI}=1.5-43.1), 6.3(95 \%$ $\mathrm{CI}=2.0-21.8)$ and $6.3(95 \% \mathrm{CI}=1.4-40.6)$. Although bleeding from the nose (study $1 \%$; control $0 \%$ ), burning sensation in the throat (study 11\%; control $8 \%$ ), headache (study 9\%; control 5\%), muscle cramps (study 8\%; control $6 \%$ ), dizziness (study $7 \%$; control $3 \%$ ) and fainting attacks (study 1\%; control 0\%) were more common in the study group, the differences were not statistically significant. Sneezing (study $10 \%$; control $12 \%$ ), runny nose (study $8 \%$; control $12 \%$ ) and sweating (study $1 \%$; control 18\%) were more common in the control group. Of these, only sweating was significant with an OR of $0.1(95 \%$ $\mathrm{CI}=0.01-0.27)$.

The proportion of participants who experienced MFF was significantly higher among the study group than in the control group (Table 2) with an OR of $7.6(95 \% \mathrm{CI}=2.5$ 26.2). Of the 36 who were identified as having MFF, 29 (29/ $36=81 \%$ ) have been in the industry for more than 5 years.

The mean and median whole blood copper and zinc levels were lower than the normal reference values. However, the study group had a significantly higher mean 
Table 1. Comparison of chronic symptoms

\begin{tabular}{|c|c|c|c|c|}
\hline Symptom & Study & Control & $\begin{array}{c}\text { Odds Ratio } \\
(95 \% \text { CI) }\end{array}$ & Probability \\
\hline Anorexia* & $\begin{array}{c}33 \\
(20.9 \%)\end{array}$ & $\begin{array}{c}12 \\
(7.7 \%)\end{array}$ & $\begin{array}{c}3.3 \\
(1.6-7.0)\end{array}$ & $<0.01$ \\
\hline Nausea** & $\begin{array}{c}9 \\
(5.8 \%)\end{array}$ & $\begin{array}{c}10 \\
(6.5 \%)\end{array}$ & $\begin{array}{c}9 \\
(0.4-2.2)\end{array}$ & 1.00 \\
\hline Distaste* & $\begin{array}{c}33 \\
(21.4 \%)\end{array}$ & $\begin{array}{c}4 \\
(2.6 \%)\end{array}$ & $\begin{array}{c}8.3 \\
(2.9-23.3)\end{array}$ & $<0.01$ \\
\hline Abdominal pain* & $\begin{array}{c}24 \\
(15.6 \%)\end{array}$ & $\begin{array}{c}25 \\
(16.2 \%)\end{array}$ & $\begin{array}{c}0.9 \\
(0.5-1.8)\end{array}$ & 1.00 \\
\hline Burning sensation of stomach* & $\begin{array}{c}28 \\
(18.2 \%)\end{array}$ & $\begin{array}{c}17 \\
(11.0)\end{array}$ & $\begin{array}{c}1.8 \\
(0.9-3.6)\end{array}$ & 0.10 \\
\hline Constipation** & $\begin{array}{c}1 \\
(0.6 \%)\end{array}$ & 0 & Undefined & 1.00 \\
\hline Numbness* & $\begin{array}{c}36 \\
(23.4 \%)\end{array}$ & $\begin{array}{c}30 \\
(19.5 \%)\end{array}$ & $\begin{array}{c}1.2 \\
(0.7-2.1)\end{array}$ & 0.51 \\
\hline Aches and pains* & $\begin{array}{c}93 \\
(60.4 \%)\end{array}$ & $\begin{array}{c}48 \\
(30.1 \%)\end{array}$ & $\begin{array}{c}4.0 \\
(2.3-7.0)\end{array}$ & $<0.01$ \\
\hline
\end{tabular}

Total number of pairs $=154$; Statistical tests: $*$ Mc Nemar's test, $* *$ Binomial test

Table 2. Comparison of acute symptoms*

\begin{tabular}{|c|c|c|c|c|c|c|}
\hline \multirow[t]{2}{*}{ Symptom } & \multicolumn{2}{|c|}{ Study $(n=154)$} & \multicolumn{2}{|c|}{ Control $(n=104)$} & \multirow{2}{*}{$\begin{array}{c}\text { Odds Ratio } \\
(95 \% \text { CI) }\end{array}$} & \multirow[t]{2}{*}{ Probability } \\
\hline & Yes & No & Yes & $\mathrm{No}$ & & \\
\hline Cough & $\begin{array}{c}27 \\
(17.5 \%)\end{array}$ & $\begin{array}{c}127 \\
(82.5 \%)\end{array}$ & $\begin{array}{c}5 \\
(4.8 \%)\end{array}$ & $\begin{array}{c}99 \\
(95.2 \%)\end{array}$ & $\begin{array}{c}4.2 \\
(1.5-13.0)\end{array}$ & 0.004 \\
\hline $\mathrm{SOB}^{* *}$ & $\begin{array}{c}24 \\
(15.6 \%)\end{array}$ & $\begin{array}{c}130 \\
(84.4 \%)\end{array}$ & $\begin{array}{c}7 \\
(6.7 \%)\end{array}$ & $\begin{array}{c}97 \\
(93.3 \%)\end{array}$ & $\begin{array}{c}2.6 \\
(1.0-6.8)\end{array}$ & 0.051 \\
\hline Dry nose & $\begin{array}{c}18 \\
(11.7 \%)\end{array}$ & $\begin{array}{c}136 \\
(88.3 \%)\end{array}$ & $\begin{array}{c}2 \\
(1.9 \%)\end{array}$ & $\begin{array}{c}102 \\
(98.1 \%)\end{array}$ & $\begin{array}{c}6.8 \\
(1.5-43.1)\end{array}$ & 0.008 \\
\hline Tearing & $\begin{array}{c}31 \\
(20.1 \%)\end{array}$ & $\begin{array}{c}123 \\
(79.9 \%)\end{array}$ & $\begin{array}{c}4 \\
(3.8 \%)\end{array}$ & $\begin{array}{c}100 \\
(96.2 \%)\end{array}$ & $\begin{array}{c}6.3 \\
(2.0-21.8)\end{array}$ & $<0.001$ \\
\hline Itchy eyes & $\begin{array}{c}17 \\
(11.0 \%)\end{array}$ & $\begin{array}{c}137 \\
(89.0 \%)\end{array}$ & $\begin{array}{c}2 \\
(1.9 \%)\end{array}$ & $\begin{array}{c}102 \\
(98.1 \%)\end{array}$ & $\begin{array}{c}6.3 \\
(1.4-40.6)\end{array}$ & 0.012 \\
\hline Sweating & $\begin{array}{c}2 \\
(01.3 \%)\end{array}$ & $\begin{array}{c}152 \\
(98.7 \%)\end{array}$ & $\begin{array}{c}19 \\
(18.3 \%)\end{array}$ & $\begin{array}{c}85 \\
(81.7 \%)\end{array}$ & $\begin{array}{c}0.1 \\
(0.01-0.27)\end{array}$ & $<0.001^{\#}$ \\
\hline MFF & $\begin{array}{c}36 \\
(23.4 \%)\end{array}$ & $\begin{array}{c}118 \\
(76.6 \%)\end{array}$ & $\begin{array}{c}4 \\
(3.8 \%)\end{array}$ & $\begin{array}{c}100 \\
(96.2 \%)\end{array}$ & $\begin{array}{c}7.6 \\
(2.5-26.2)\end{array}$ & $<0.001$ \\
\hline
\end{tabular}

Statistical test: chi-square test; *only the symptoms which were significant are included in the table; ${ }^{* *}$ shortness of breath; ${ }^{*}$ significantly higher among the control group. MFF-metalic fume fever

value than the control group for both copper and zinc levels. The median test was applied since both copper and zinc values did not show a normal distribution and the study group was found to have a significantly higher percentage of subjects with more than the median levels of both blood copper and zinc (Table 3 ). The zinc levels were elevated more than the normal level in $18(12 \%)$ in the study and $2(1 \%)$ in the control group. The copper levels were elevated more than the normal in $8(5 \%)$ and $1(1 \%)$ in the control group (Table 4$)$. Two (1\%) from the study group had both levels elevated. Anorexia and distaste in relation to increased copper and zinc levels were present only in the study group participants (Table 5).
The proportions with MFF with increased levels of copper or zinc were higher in the study group and these differences were not statistically significant. The two (1\%) brass workers who had elevated levels of both zinc and copper had anorexia, distaste and MFF.

The mean haemoglobin levels were $14.8 \mathrm{~g} / \mathrm{dL}$ (range: 12.0-17.2 g/dL) and $15.0 \mathrm{~g} / \mathrm{dL}$ (range: $12.4-17.0 \mathrm{~g} / \mathrm{dL}$ ) for study and control groups. The difference was not significant.

The dry bulb temperature varied from $26^{\circ} \mathrm{C}$ to $36^{\circ} \mathrm{C}$, and the WBGT index from $22.5^{\circ} \mathrm{C}$ to $28.2^{\circ} \mathrm{C}$. The air velocity was between $0.33 \mathrm{~m} / \mathrm{sec}$ and $0.70 \mathrm{~m} / \mathrm{sec}$, which is above the recommended level of $0.05-0.15 \mathrm{~m} / \mathrm{sec}$ [11]. 
Table 3. Comparison of blood copper and zinc levels

\begin{tabular}{|c|c|c|c|}
\hline & & $\begin{array}{l}\text { Copper } \\
(\mu g / d L)\end{array}$ & $\begin{array}{c}\text { Zinc } \\
(\mu g / d L)\end{array}$ \\
\hline \multicolumn{2}{|c|}{ Reference range } & $80-120$ & $860-900$ \\
\hline \multirow[t]{3}{*}{ Median } & Study + Control & 65.5 & 617.0 \\
\hline & Study & 71.3 & 697.1 \\
\hline & Control & 63.3 & 559.1 \\
\hline \multirow[t]{2}{*}{ Mean } & Study & 73.97 & 678.92 \\
\hline & Control & 64.35 & 574.68 \\
\hline \multirow[t]{2}{*}{ Range } & Study & $32.0-185.2$ & $324.0-1106.0$ \\
\hline & Control & $33.1-123.7$ & $327.0-0910.0$ \\
\hline \multicolumn{2}{|c|}{ Difference in mean } & 9.62 & 104.24 \\
\hline \multicolumn{2}{|c|}{ Standard error } & 2.18 & 15.95 \\
\hline \multicolumn{2}{|c|}{ Probability } & $<0.001$ & $<0.001$ \\
\hline
\end{tabular}

Number in each group $=154$; Statistical test: Paired t-test

Table 4. Blood copper and zinc levels by the two groups

\begin{tabular}{|c|c|c|c|c|c|}
\hline Trace element & & $\begin{array}{c}\text { Study } \\
n=154\end{array}$ & $\begin{array}{l}\text { Control } \\
n=154\end{array}$ & Probability & $\begin{array}{c}\text { Odds ratio } \\
(95 \% \mathrm{CI})\end{array}$ \\
\hline $\begin{array}{l}\text { Copper } \\
(\mu \mathrm{g} / \mathrm{dL})\end{array}$ & $\begin{array}{l}\leq \mathrm{M} \\
>\mathrm{M}\end{array}$ & $\begin{array}{l}61(39.6 \%) \\
93(60.4 \%)\end{array}$ & $\begin{array}{l}94(61.0 \%) \\
60(39.0 \%)\end{array}$ & 0.0001 & $\begin{array}{c}2.8 \\
(1.7-4.9)\end{array}$ \\
\hline $\begin{array}{l}\text { Zinc } \\
(\mu \mathrm{g} / \mathrm{dL})\end{array}$ & $\begin{array}{l}\leq \mathrm{M} \\
>\mathrm{M}\end{array}$ & $\begin{array}{l}57(37.0 \%) \\
97(63.0 \%)\end{array}$ & $\begin{array}{l}97(63.0 \%) \\
57(37.0 \%)\end{array}$ & $<0.0001$ & $\begin{array}{c}4.1 \\
(2.2-7.5)\end{array}$ \\
\hline
\end{tabular}

Statistical test: Mc Nemar's test; $\mathrm{M}=$ median

Table 5. Distribution of symptoms by high blood copper and zinc levels

\begin{tabular}{lcccc}
\hline Symptom & \multicolumn{2}{c}{ Copper $>120 \mu \mathrm{g} / \mathrm{dL}$} & \multicolumn{2}{c}{ Zinc $>900 \mu \mathrm{g} / \mathrm{dL}$} \\
\cline { 2 - 4 } & \multicolumn{1}{c}{ Study } & Control & Study & Control \\
& $n=8$ & $n=1$ & $5(3.2 \%)$ & $n=2$ \\
\hline Anorexia & $2(1.3 \%)$ & 0 & 0 & 0 \\
Nausea & $2(1.3 \%)$ & 0 & $7(4.5 \%)$ & 0 \\
Distaste & $2(1.3 \%)$ & 0 & $3(1.9 \%)$ & 0 \\
Abdominal pain & $1(0.6 \%)$ & 0 & $3(1.9 \%)$ & $2(1.3 \%)$ \\
Burning sensation & $3(1.9 \%)$ & 0 & $2(1.3 \%)$ & $2(1.3 \%)$ \\
Numbness & $2(1.3 \%)$ & 0 & $13(8.7 \%)$ & $1(0.6 \%)$ \\
MFF & $5(3.2 \%)$ & $1(0.6 \%)$ & $2(1.3 \%)$ \\
\hline
\end{tabular}

Two from study group had both copper and zinc levels elevated. Percentages calculated from 154

The recommended WBGT level of $26.1^{\circ} \mathrm{C}$ for an air velocity of less than $1.53 \mathrm{~m} / \mathrm{sec}$ for heavy work [12] (considering smelting as heavy work) exceeded only in two workshops. In these two workshops, three out of the five workers complained of muscle cramps. The worker who had a history of fainting attacks did not work in any of these two workshops.

\section{Discussion}

The control group was selected from the local population which introduces a selection bias [13] due to the phenomenon of "healthy worker effect" (HWE) [14]. HWE occurs due to lower morbidity and mortality rates experienced by working populations compared to the general population. This underestimates the strength of association between exposure and outcome. The symptoms inquired were subjective and the reliability of these may be doubtful. However, a standard questionnaire was used to elicit the presence of these symptoms from both the groups, which ensured uniformity in eliciting the symptoms. Reliability was measured by computing Kappa coefficients, which varied between 55\% and 90\%.

GI symptoms such as loss of appetite, distaste and burning sensation were higher among the brass workers although only the former two were significant. Presence of these symptoms may be attributed to exposure to zinc. Several GI symptoms ranging from gastroenteritis to gastric and peptic ulcers have been described in workers exposed to zinc in a galvanizing plant [7]. The furnace 
operators in a brass foundry were reported to have significantly higher zinc levels in red blood cells, whole blood and fasting gastric juice [5]. The whole blood zinc levels in the latter study were similar to the findings of the present study.

The acute symptoms such as cough, shortness of breath, excessive tearing and itchy eyes were significantly more in the study group. Such symptoms are likely to occur due to exposure to various types of dusts, fumes and smoke which is a feature in the brass industry. The only acute symptom that was significantly frequent in the control group was sweating, and this was because $36 \%$ of them were working outdoors $(12 \%$ each of farmers and casual workers and $6 \%$ each of labourers and masons).

MFF is a condition that occurs in novices, $70-75 \%$ of whom develop tolerance with time [2]. Although it is benign, its recurring nature during the initial phases of employment, may make people resign from their jobs. In the present study, $81 \%$ of the workers who suffered MFF had worked for more than 5 years, which suggests that development of tolerance has not been a regular feature. Four subjects (4\%) in the control group also had symptoms suggestive of MFF which is difficult to explain on their outdoor occupational histories.

Both mean and median levels of copper and zinc were lower than the established reference levels $[15,16]$, which emphasises the need to determine local values. Eight (5.2\%) had elevated copper levels while 18 (11.7\%) had elevated zinc levels among the brass workers and all of them presented with either one or more of the symptoms investigated. This suggests an association between symptoms and excess levels of zinc and copper $[17,18]$.

Only one brass worker (1\%) fainted while at work whereas the proportion of workers who have fainted at work was $4.9 \%$ and $1.3 \%$ respectively in a study done on iron and steel foundries in Sri Lanka [10]. Fifteen per cent workers in these foundries [10] had complained of muscle cramps in comparison to $8.4 \%$ of brass workers. The proportion of brass workers who experienced muscle cramps was higher than that of the control group (5.8\%), although the difference was not statistically significant. Both groups were equally at risk of this condition considering the fact that a certain proportion of the control group worked outdoors.

Intense sweating reported was as high as $75 \%$ in the iron and steel foundries in comparison to only $1.3 \%$ among brass workers. The low rates observed in the brass workshops may be explained by the fact that the recommended WBGT values were exceeded only in two workshops (20\%), whereas in the iron and steel foundries, it was exceeded in $29 \%$ of the 89 observations made.

Brass manufacturing is a small scale industry. The owners of these factories are unable to invest capital on personal protective equipment (PPE) and other preventive measures. Workers themselves are not knowledgeable about the associated health hazards and therefore, do not realise the importance of preventive measures. Furthermore, the use of PPE may cause discomfort owing to the climatic conditions experienced in the tropical countries. These factors account for the difficulty in ensuring a suitable work environment for the brass workers, but measures to improve awareness should overcome these difficulties, at least to a certain degree.

\section{Acknowledgements}

I thank the brass workers for participating in the study, Prof. MA Fernando for his advice and guidance, National Science Foundation for the funds, and Mrs Janaki Ariyawansa for typing the manuscript.

\section{References}

1. Jayawardana PL, de Alwis WR, Fernando MA. Ventilatory function in brass workers of Gadaladeniya, Sri Lanka. Occupational Medicine 1997; 47: 411-6.

2. Hayhurst ER. Occupational brass poisoning: Brass founder's ague. American Journal of Medical Science 1913; 145: 723-39.

3. Cohen SR. A review of the health hazards from copper exposure. The Journal of Occupational Medicine 1974; 16: $621-4$.

4. Batchelor RP, Fehnel JW, Thomson RM, Drinker KR. A clinical and laboratory investigation of the effect of metallic zinc, of zinc oxide and of zinc sulphide upon the health of workmen. The Journal of Industrial Hygiene 1926; 8: 322-63.

5. Hamdi EA. Chronic exposure to zinc of furnace operators in a brass foundry. British Journal of Industrial Medicine 1969; 26: 126-34.

6. Logue JN, Koonntz MD, Hattwick MAW. A historical prospective mortality study of workers in copper and zinc refineries. Journal of Occupational Medicine 1982; 24: 398-408.

7. McCord CP, Friedlander A, Brown WE, Minster DK. An occupational disease among zinc workers. Archives of Internal Medicine 1926; 37: 641-59.

8. Armstrong CW, Moore LW Jr., Hackler RL, Miller GB, Stroube RB. An outbreak of metal fume fever. Journal of Occupational Medicine 1983; 25: 886-8.

9. Dukes - Dobos FN. Hazards of heat exposure. A review. Scandinavian Journal of Work Environment and Health 1981; 7: 73-83.

10. Lankatilake KN, De Fonseka TEJ. A survey of the thermal environment, sound and illuminance in an iron and steel foundry and related health effects. Ceylon Medical Journal 1990: 35: 109-17.

11. Bhattacharya SK, Tripathi SR, Kashyap S. A study of heat and noise problems in a drug and pharmaceutical firm in India. Industrial Health 1990; 28: 203-7. 
12. Parikh DJ, Pandya CB, Ramanathan NL. Applicability of the WBGT index of heat stress to work situations in India. Indian Journal of Medical Research 1976; 64: 327-35.

13. Jayawardana PL. Occupational Health Hazards of Brass Workers in a Selected Community. MD Thesis; Post Graduate Institute of Medicine, University of Colombo, 1994.

14. Choi BCK. Definition, sources, magnitude, effect modifiers, and strategies of reduction of the healthy worker effect. Journal of Occupational Medicine 1992; 34: 979-88.

15. Underwood EJ. In: Trace Elements in Human and Animal Nutrition. 2nd rev. ed. New York: Academic Press Inc., 1962: 61
16. Pagliuca A, Mufti GJ, Baldwin D, Lestas AN, Wallis RM, et al. Lead poisoning: clinical, biochemical and haematological aspects of a recent outbreak. Journal of Clinical Pathology 1990; 43: 277-81.

17. Cullen MR, Robins JM, Eskenazi B. Adult inorganic lead intoxication: Presentation of 31 new cases and a review of recent advances in the literature. Medicine (Baltimore) 1983; 62: 221-47.

18. Waldron HA. In : Lecture Notes in Occupational Medicine. 3rd ed. Oxford: Blackwell Scientific Publications, 1985: 163-190.

\section{We need more free condoms}

Condoms are so effective at preventing the spread of sexually transmitted disease that if they were consistently used, the spread of HIV would be a mere trickle rather than the deluge that it is. When used consistently, the $90-95 \%$ effectiveness of condoms exceeds that of many vaccines, including cholera (66\%), influenza (70-90\%), and varicella (70$90 \%$ ). In an HIV epidemic that is wiping out entire generations in some countries, we should give first priority to ensuring that everyone who needs a condom has one.

DA Cohen, TA Farley. Social marketing of condoms is great, but we need more free condoms. Lancet 2004; 364: 13-4. 